\title{
Ranking of energy consumption objects using the principal components method
}

\author{
A. Perekrest \\ Kremenchuk Mykhailo Ostrohradskyi National \\ University, \\ Ukraine \\ E-mail: pksg13@gmail.com \\ O. Vovna \\ Donetsk National Technical University, \\ Ukraine \\ E-mail: Oleksandr.Vovna@donntu.edu.ua
}

\author{
V. Ogar \\ Kremenchuk Mykhailo Ostrohradskyi National \\ University, \\ Ukraine \\ E-mail: Vita.Ogar@gmail.com
}

\author{
M. Kushch-Zhyrko \\ Kremenchuk Mykhailo Ostrohradskyi National \\ University, \\ Ukraine \\ E-mail: k.zh.mhl@gmail.com
}

\begin{abstract}
Ensuring comfortable conditions in civil buildings requires the implementation of tasks of monitoring and forecasting the cost of energy resources, as well as energy-efficient management of heating engineering systems and its equipment. The implementation of appropriate automation and monitoring solutions allows the accumulation of a significant amount of data. To increase the informativeness of the analysis of energy efficiency in the operation of civil buildings a model of their information ranking was developed using correlation analysis and the principal component analysis. Based on the interdisciplinary methodology of data analysis (CRISP-DM), the basic indicators were determined for the accepted initial conditions on electricity and heat consumption of the university buildings and the matrix of correlation coefficients of their interrelation was estimated. Certain data (external volume and area of the building and average temperature values for this region according to the norm) are obtained from the technical documentation of buildings and available from open sources, others (amount of consumed heat and electricity, indoor temperature) are determined during operation and characterize the efficiency of energy resources in the building. At the initial stage, a correlation analysis of the relationship between the main parameters that characterize buildings and their consumption of energy resources. The principal component analysis was used to reduce the dimensionality of the feature set of data and to identify homogeneous groups of energy consumption objects. The obtained four components explain about $90 \%$ of the variance of the initial data and characterize the efficiency of energy use in terms of temperature, volume and coefficient of heating degree days of the heating season. The obtained results are recommended for implementation in modern systems of energy monitoring and municipal energy management as applied models for diagnosing abnormal situations and sound management decisions.
\end{abstract}

Keywords - buildings; energy consumption; principal components; machine learning; data segmentation.

\section{INTRODUCTION}

The development of information technology has led to an increase in the number of machine learning methods application areas and methodologies of its application [14]. These include managing the energy consumption of civil buildings and forecasting energy costs to ensure comfortable conditions. Machine learning methods help in the energy management systems parameters analyzing and support effective decision-making by energy managers [5].

There is a need to improve existing or find new approaches of energy consumption data analysis, in order to make decisions aimed at improving energy efficiency.

Implementation of solutions for heating systems automated monitoring and control allows to reduce the total heat consumption and accumulate large amounts of information about the operation of the system and the decisions made by the energy manager. Tasks related to the need to ensure regulatory sanitary and hygienic conditions in heated rooms, taking into account the influence of external factors $[6,7]$

\section{EXISTING SOLUTIONS ANALYSIS}

The implementation of solutions aimed at controlling and monitoring energy consumption allows to accumulate significant amounts of information about the amount of resource consumed [4, 5]. The availability of meter readings gives an idea about heat consumption, which can affect management strategies, such as the allocation of nonobvious patterns of consumption of communal or any buildings - information that can not be obtained without the use of machine learning methods. The main problem you may face is the complexity, and often the inability, to obtain reliable and detailed data.

In previous works $[8,9]$ the structure of information flows for obtaining data from available sources was developed. Features of data depending on type and 
functional features of buildings are established. The study of the data structure confirmed the need to create additional features for the analysis of energy consumption of buildings in the form of specific heat consumption, taking into account outdoor and indoor air temperatures, energy efficiency class and tariffs per unit of heating area. Taking into account the complex structure of data on energy consumption of buildings, a method of initial analysis based on the intersectoral methodology CRISP-DM [4] has been developed. The conducted approbation of the methodology on the data of educational buildings of KrNU allows to state that this algorithm can be used for preliminary data analysis on the basis of Data Mining tools in the future.

\section{PURPOSE OF THE WORK}

Designing new features to compare the energy consumption of buildings leads to an increase in the dimensionality of the data and, consequently, an increase in the time to perform various actions on the data, which can be critical for larger samples over long periods of time. Thus, the aim of the study is to develop and test a model of information ranking of buildings according to their energy consumption using the method of principal components.

\section{RESEARCH MATERIALS}

Three data sets were collected for this study:

- Energy consumption of educational buildings for the period from 2012 to 2016, indicating the building number, month, year, heat consumption (expressed in Gcal), electricity consumption (expressed in $\mathrm{kWh}$ ). Number of data: columns - 5, rows - 420. Data format: case number categorical variable, the rest of the data - numerical.

- Volumes of heat load, indicating the building number, heat load volumes (expressed in Gcal / h) and building volume. Number of data: columns -3 , rows -7 . Data format: case number - categorical variable, the rest of the data - numerical.

- Average monthly ambient temperature for the period from 2012 to 2016, indicating the year, month and average monthly temperature. Number of data: columns -3 , rows 60. Data format: all data - numerical.

For comparative analysis of energy consumption of different buildings, the same indicators were used, for example, specific heat consumption $\left(\mathrm{q} 1, \mathrm{kWh} / \mathrm{m}^{3}\right)$, specific electricity consumption $\left(\mathrm{q} 2, \mathrm{kWh} / \mathrm{m}^{3}\right)$, etc.

Normative value of degree days of the heating period (GDOP):

$$
\operatorname{Dd}_{H}=\left(T_{\text {in }}-T_{\text {out_norm }}\right) \cdot Z_{\text {norm }} \text {, }
$$

where $\mathrm{Dd}_{\mathrm{H}}-$ normalized number of degree days; $\mathrm{T}_{\text {in }}=20, \quad{ }^{\circ} \mathrm{C} \quad-\quad$ internal room temperature; $\mathrm{T}_{\text {out_norm }}=-0.8,{ }^{\circ} \mathrm{C}-$ average normalized outdoor temperature; $Z_{\text {norm }}=180-$ standard duration of the heating period.

The actual value of the degree-days of the heating period (HDD):

$$
\mathrm{Dd}=\left(\mathrm{T}_{\text {in_C }}-\mathrm{T}_{\text {out_C }}\right) \cdot \mathrm{Z},
$$

where $\mathrm{Dd}$ - the actual number of degree days; $\mathrm{T}_{\text {in_C }}$, ${ }^{\circ} \mathrm{C}$ - internal room temperature; $\mathrm{T}_{\text {out_C}},{ }^{\circ} \mathrm{C}$ - average actual outdoor temperature; $\mathrm{Z}$ - the actual duration of the heating period.

HDD coefficient:

$$
\mathrm{K}_{\mathrm{Dd}}=\frac{\mathrm{Dd}_{\mathrm{n}}}{\mathrm{Dd}}
$$

where $\mathrm{K}_{\mathrm{Dd}}-\mathrm{HDD}$ coefficient; $\mathrm{Dd}-$ the actual number of degree-days; $\mathrm{Dd}_{\mathrm{n}}-$ normalized number of degrees-days.

Absolute heat consumption in $\mathrm{kWh}$ :

$$
\mathrm{E} \_\mathrm{kWh}=1163 \mathrm{E} \_\mathrm{Gkal} \text {, }
$$

where $\mathrm{E} \_\mathrm{kWh}$ - absolute heat consumption, in $\mathrm{kWh}$; E_Gkal - thermal energy consumption, Gcal.

Specific heat consumption:

$$
\mathrm{q} 1=\frac{\mathrm{E} \_\mathrm{kWh}}{\mathrm{V}},
$$

where $\mathrm{q} 1-$ specific heat consumption, $\mathrm{kWh}$ $/ \mathrm{m}^{3} ; \mathrm{E} \_\mathrm{kWh}$ - thermal energy consumption, kWh; V volume of the building, $\mathrm{m}^{3}$.

Specific power consumption:

$$
\mathrm{q} 2=\frac{\mathrm{W} \_\mathrm{kWh}}{\mathrm{V}},
$$

where $\mathrm{q} 2-$ specific electricity consumption, $\mathrm{kWh} / \mathrm{m}^{3}$; $\mathrm{W} \_\mathrm{kWh}$ - electricity consumption, kWh; V-volume of the building, $\mathrm{m}^{3}$.

Total energy consumption:

$$
\text { Esum_kWh }=E \_k W h+W \_k W h,
$$

where Esum_kWh - total energy consumption, kWh; E_kWh - thermal energy consumption, kWh; W_kWh electricity consumption, $\mathrm{kWh}$.

Specific total energy consumption:

$$
\mathrm{q} 3=\frac{\text { Esum_kWh }}{\mathrm{V}},
$$

where q3 - specific total energy consumption, kWh $/ \mathrm{m}^{3}$; Esum_kWh - specific energy consumption, kWh; V - volume of the building, $\mathrm{m}^{3}$.

Specific heat consumption, reduced to the normative values of external and internal air temperature:

$$
\mathrm{q} 1 \mathrm{t}=\mathrm{q} 1 \cdot \mathrm{K}_{\mathrm{Dd}},
$$


A. Perekrest, O. Vovna, V. Ogar, M. Kushch-Zhyrko Issue 57, Vol. 1.

where q1t - specific heat consumption taking into account temperatures, $\mathrm{kWh} / \mathrm{m}^{3} ; \mathrm{q} 1-$ specific heat consumption, $\mathrm{kWh} / \mathrm{m}^{3} ; \mathrm{K}_{\mathrm{Dd}}-\mathrm{HDD}$ coefficient.

Specific power consumption, reduced to the normative values of external and internal air temperature:

$$
\mathrm{q} 2 \mathrm{t}=\mathrm{q} 2 \cdot \mathrm{K}_{\text {Dd }},
$$

where $\mathrm{q} 2 \mathrm{t}$ - specific power consumption taking into account temperatures, $\mathrm{kWh} / \mathrm{m}^{3} ; \mathrm{q} 2$ - specific electricity consumption, $\mathrm{kWh} / \mathrm{m}^{3} ; \mathrm{K}_{\mathrm{Dd}}-\mathrm{HDD}$ coefficient.

Specific total energy consumption, reduced to the normative values of external and internal air temperature:

$$
\mathrm{q} 3 \mathrm{t}=\mathrm{q} 3 \cdot \mathrm{K}_{\mathrm{Dd}},
$$

where q3t - specific total energy consumption taking into account temperatures, $\mathrm{kWh} / \mathrm{m}^{3} ; \mathrm{q} 3$ - specific total energy consumption, $\mathrm{kWh} / \mathrm{m}^{3} ; \mathrm{K}_{\mathrm{Dd}}-\mathrm{HDD}$ coefficient.

The selected group of characteristics can be divided into two categories: a priori - obtained from the technical documentation of buildings, or available from open sources (external volume of the building and average temperature for this region by norm), and posteriori - obtained during operation of the building and actually characterize energy consumption of the building (amount of consumed heat and electricity, internal temperature in the room).

Preliminary correlation analysis is performed and an estimate of the matrix of correlation coefficients is obtained (Fig. 1). The obtained matrix of estimates of correlation coefficients is taken as a basis for further research.

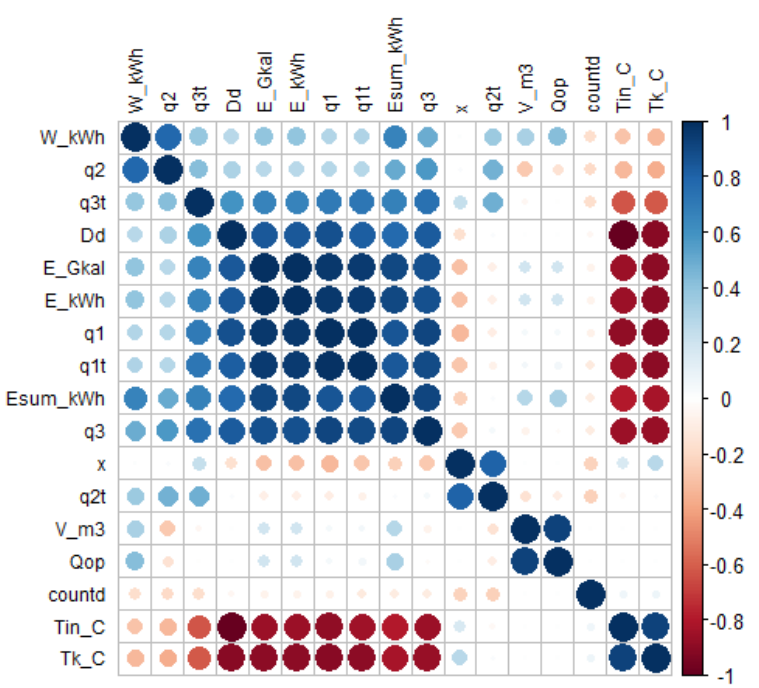

Fig. 1. Correlation coefficients matrix

Based on the nature of the data, it is advisable to use methods of correlation analysis and principal component analysis (PCA) to reduce the dimensionality of informative features and identify homogeneous groups of energy consumption objects using cluster analysis.
The purpose of PCA is to find linear combinations of variables containing the largest variance [10]. The linear combination has the following form:

$$
\begin{gathered}
Y_{1}=a_{11} X_{1}+a_{12} X_{2}+\cdots+a_{1 p} X_{p} \\
Y_{2}=a_{21} X_{1}+a_{22} X_{2}+\cdots+a_{2 p} X_{p} \\
\vdots \\
Y_{k}=a_{k 1} X_{1}+a_{k 2} X_{2}+\cdots+a_{k p} X_{p}
\end{gathered}
$$

Wherein $\sum_{\mathrm{i}=1}^{\mathrm{p}} \mathrm{a}_{1 \mathrm{i}}=1$.

Dispersion of the first head component:

$$
\operatorname{var}\left(\mathrm{Y}_{1}\right)=\mathrm{a}_{1}^{\prime} \sum \mathrm{a}_{1},
$$

where $\Sigma$ - covariance (correlation) matrix.

The variance of the second and subsequent principal components is calculated similarly.

In this model, the vectors $a_{i}^{\prime}=\left(a_{i 1}, a_{i 2}, \ldots, a_{i p}\right)^{\prime}, i=\overline{1, p} \quad$ represent the eigenvectors of the covariance (correlation) matrix $\Sigma$, whereas the variance of the -th principal component is equal to the eigenvalue of the covariance matrix (correlation):

$$
\operatorname{var}\left(\mathrm{Y}_{1}\right)=\lambda_{\mathrm{i}}
$$

The total variance of the sample is equal to:

$$
\sum_{\mathrm{i}=1}^{\mathrm{p}} \lambda_{\mathrm{i}}
$$

Performing the PCA procedure allows to get the eigenvalues $\lambda_{i}$ of the main components and the percentage of variance that they explain (Table I).

\section{TABLE I. MAIN COMPONENTS VALUES}

\begin{tabular}{|c|l|l|l|}
\hline comp & eigenvalue & $\begin{array}{c}\text { percentage of } \\
\text { variance }\end{array}$ & $\begin{array}{c}\text { cumulative } \\
\text { percentage } \\
\text { of variance }\end{array}$ \\
\hline comp 1 & 7,7733498 & 48,5834363 & 48,58344 \\
\hline comp 2 & 2,7178720 & 16,9866997 & 65,57014 \\
\hline comp 3 & 2,3300882 & 14,5630513 & 80,13319 \\
\hline comp 4 & 1,4952653 & 9,3454084 & 89,47860 \\
\hline comp 5 & 0,7287498 & 4,5546865 & 94,03328 \\
\hline comp 6 & 0,3633305 & 2,2708157 & 96,30410 \\
\hline comp 7 & 0,2747271 & 1,7170444 & 98,02114 \\
\hline comp 8 & 0,1548087 & 0,9675546 & 98,98870 \\
\hline comp 9 & 0,1130121 & 0,7063254 & 99,69502 \\
\hline comp 10 & 0,0288535 & 0,1803346 & 99,87536 \\
\hline comp 11 & 0,0190971 & 0,1193566 & 99,99471 \\
\hline comp 12 & 0,0008458 & 0,0052864 & 100,00000 \\
\hline
\end{tabular}

Obtained 4 main components, explaining $89.4786 \%$ of the dispersion.

Fig. 2 shows the variance of the weights of the main components. 


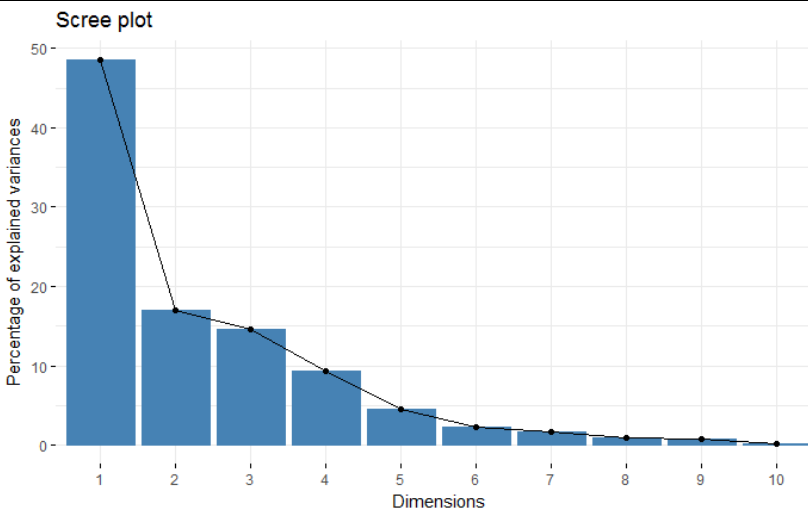

Fig. 2. Main components weights dispersion

The dotted line in fig. $2-6$ corresponds to the expected value if the contribution of all variables is uniform. For the selected component, the contribution of any of the variables above the dashed line can be considered important.

As can be seen from fig. 3, the first main component is "loaded" by variables related to temperature and variables that characterize the absolute, specific and reduced to the normative values of external and internal air temperature heat consumption and total absolute energy consumption. Moreover, the analysis of factor loads shows that, with the internal and external environment temperature increase, the amount of heat consumption decreases respectively. This component should be called "Energy efficiency of the building by temperature", i.e. those structures are more energy efficient, which when varying the temperature have less variation in total energy consumption and heat consumption.

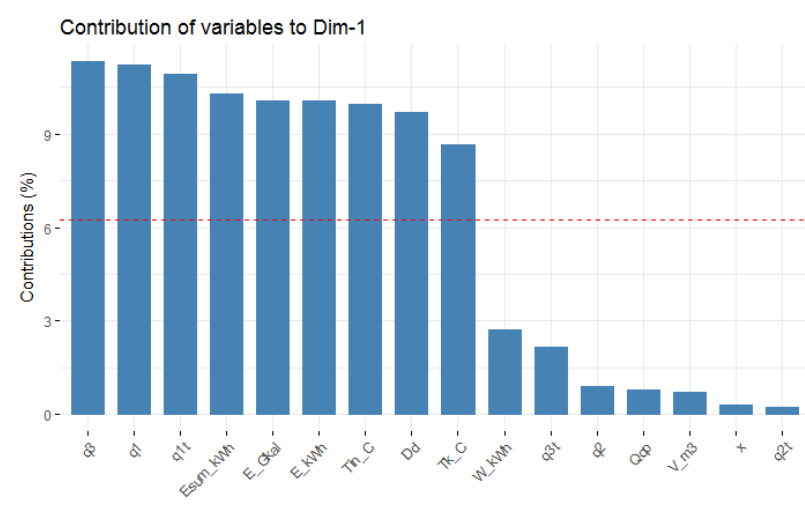

Fig. 3. First main component variables contribution

The second main component (Fig. 4) is related to the volume of the building, the amount of heat load, as well as the indicators of specific, reduced to the normative values of outdoor and indoor air temperature, electricity consumption and total energy consumption, specific electricity consumption. It can be called "Energy efficiency of a building by volume", i.e. those structures are more energy efficient that with the same volume and volume of heat load have less variation in this direction.

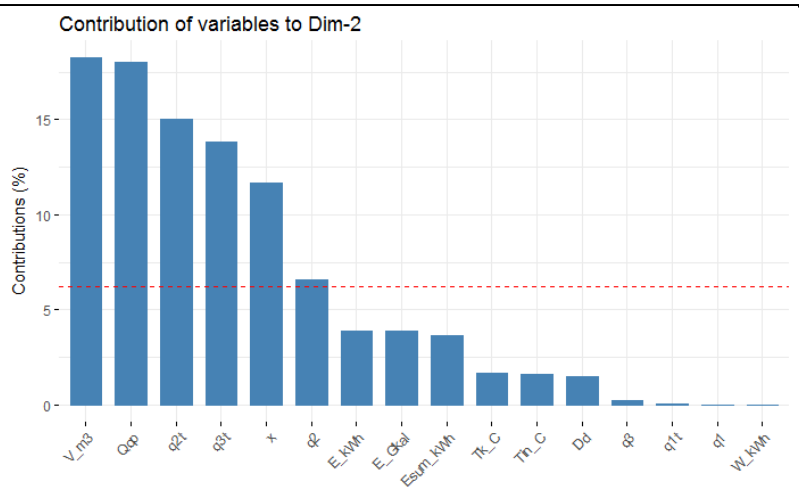

Fig. 4. Second main component variables contribution

The third main component (Fig. 5) is formed by the values of the coefficient of degrees-days, the volume of the building, the volume of heat load, as well as specific indicators, reduced to the normative values of outdoor and indoor air temperature and total energy consumption. Since the second and third components contain the same variables that significantly affect the percentage of the described variance, we can say that this phenomenon is caused by an increase in the dimensionality of the data by creating parameters that depend on the volume and value of the degree-day ratio.

The fourth main component (Fig. 6) is specific and is formed by the values of absolute and specific power consumption.

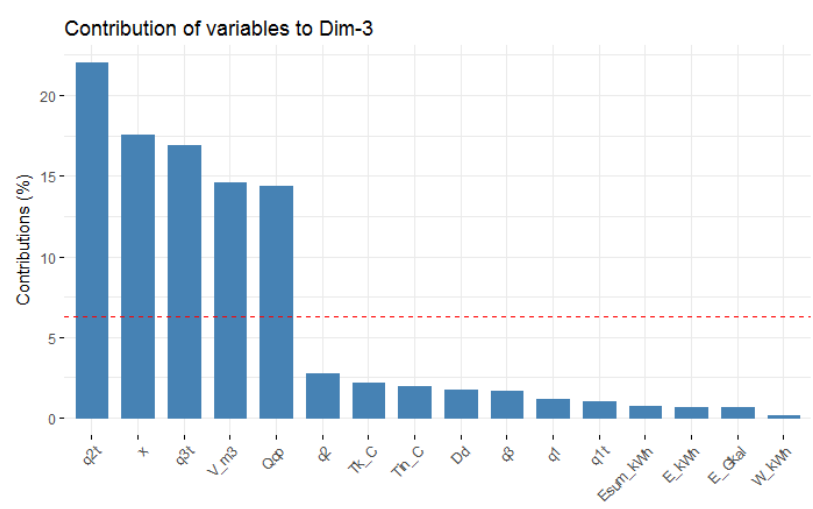

Fig. 5. Third main component variables contribution

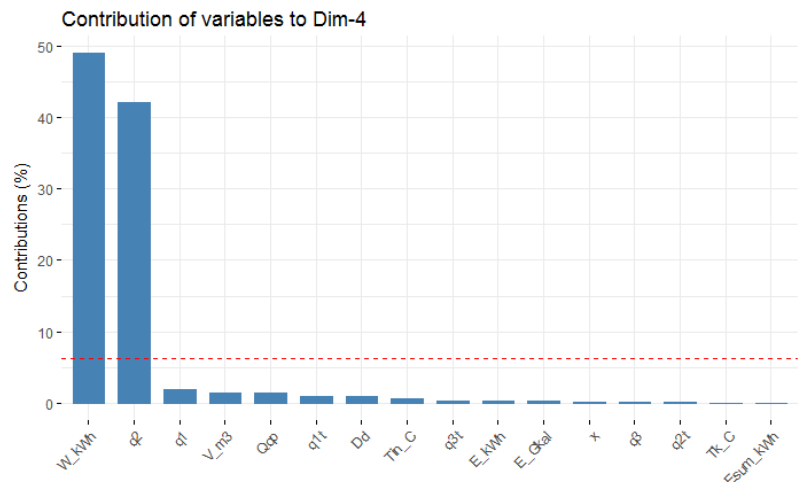

Fig. 6. Forth main component variables contribution

Below (Fig. 7) a graph of the weights of the main components is represented. 
A. Perekrest, O. Vovna, V. Ogar, M. Kushch-Zhyrko Issue 57, Vol. 1.

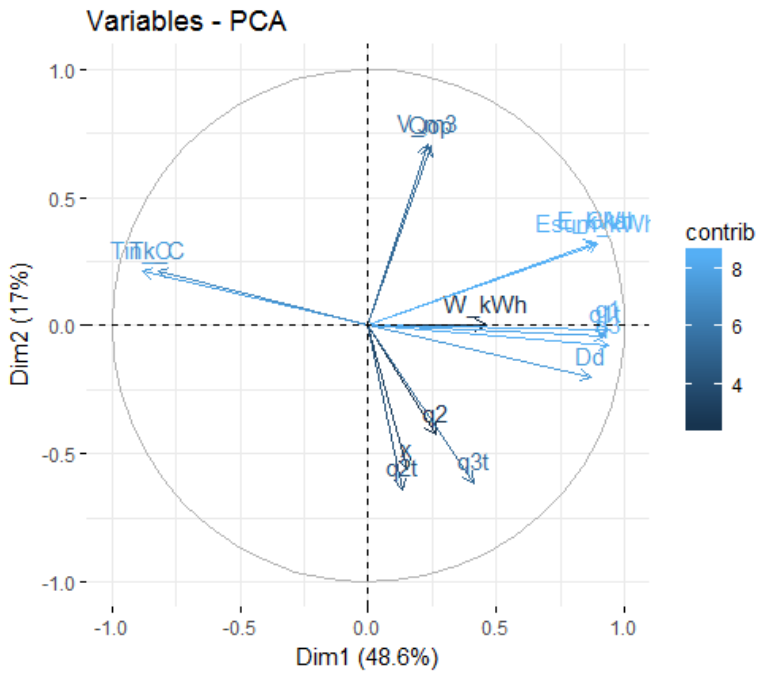

Fig. 7. Main components weights dependence

Data were segmented by buildings (Fig. $8-10$ ) by two seasons: non-heating (conditional name summer) and heating (conditional name winter) periods.

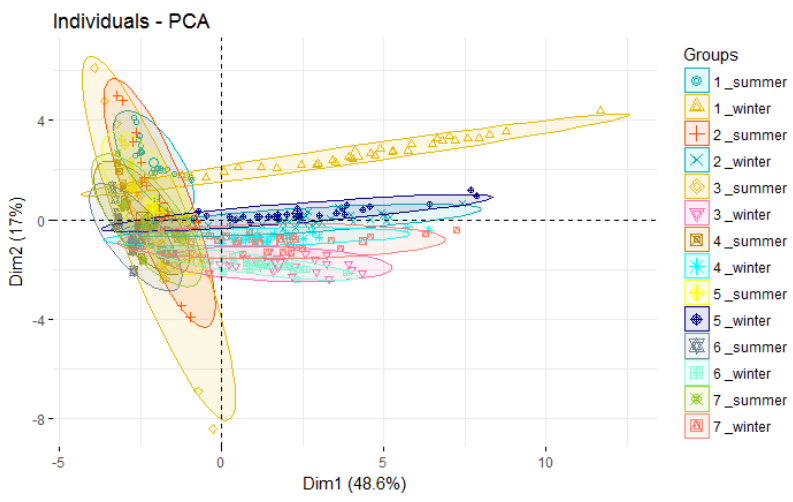

Fig. 8. Segmentation of data by seasons by the first and second components

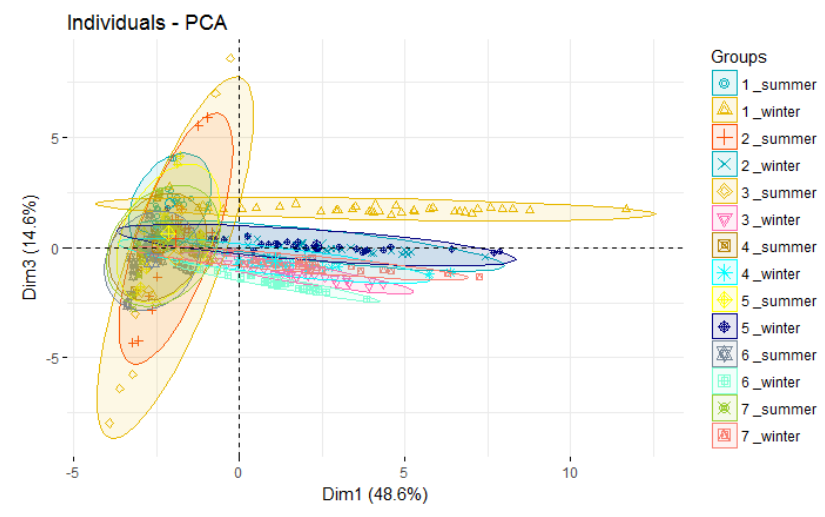

Fig. 9. Segmentation of data by seasons by the first and third components

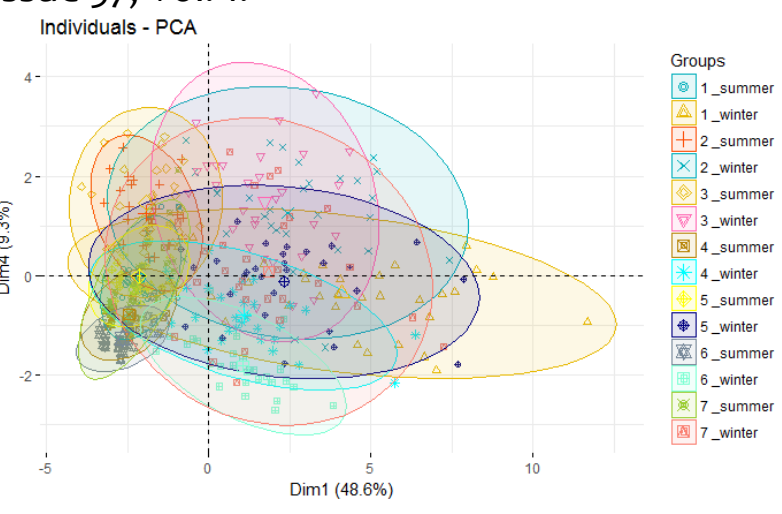

Fig. 10. Segmentation of data by seasons by the first and fourth components

The convergence of the winter period segments centers to the origin indicates an increase in electricity consumption during the heating period and transition seasons, which may be caused by the active use of climate technology.

\section{CONCLUSIONS}

Methods of correlation analysis and PCA were used to reduce the dimensionality of informative features. Four main components describing about $90 \%$ of the sample variance were obtained.

The first main component is the variables related to temperature and the variables that characterize the absolute, specific and reduced to the normative values of outdoor and indoor air temperature heat consumption and total absolute energy consumption - "Energy efficiency of the building by temperature".

The second main component is the volume of the building, the amount of heat load, the specific, reduced to the normative values of outdoor and indoor air temperature, electricity consumption and total energy consumption, the specific electricity consumption - "Energy efficiency of the building by volume".

The third main component is the degree-day ratio, the volume of the building, the amount of heat load, the specifics, reduced to the normative values of outdoor and indoor air temperature of electricity consumption and total energy consumption.

We can conclude that the hit of the same variables to the second and third main components is due to the artificial creation of parameters from the original, which in turn caused an increase in the dimensionality of the data. To exclude this anomaly, at the stage of studying the correlation matrix it is necessary to exclude variables that are strongly correlated with each other. The fourth main component depends solely on the values of absolute and specific power consumption.

The application of cluster analysis allowed to identify homogeneous groups of energy-consuming objects by selected components.

\section{REFERENCES}

[1] C. M. Bishop Pattern Recognition and Machine Learning. NY: Springer. -2006 . 
[2] Грас Дж. Data Science: Наука о данных с нуля: пер. с англ. СПб.: БХВ-Петербург, 336 с.

[3] Ситник В.Ф., Краснюк М.Т. Інтелектуальний аналіз даних. Київ: КНЕУ, 2007. - 376 с.

[4] CRISP-DM. Official website: http://crisp-dm.eu.

[5] V. Pliuhin, V. Korobka, A. Karyuk, M. Pan and M. Sukhonos, "Using Azure Machine Learning Studio with Python Scripts for Induction Motors Optimization Web-Deploy Project," 2019 IEEE International Scientific-Practical Conference Problems of Infocommunications, Science and Technology (PIC S\&T), Kyiv, Ukraine, 2019, pp. 631-634.

[6] Перекрест А. Л., Загирняк М. В. Опыт внедрения и использования автоматизированной системы мониторинга температурных режимов и удаленного управления теплопотреблением Кременчугского национального университета. Электротехнические и компьютерные системы. 2014. № 15 (91). С. 423-426.
[7] O. Vovna, I. Laktionov, S. Sukach, M. Kabanets, E. Cherevko Method of adaptive control of effective energy lighting of greenhouses in the visible optical range. Bulgarian Journal of Agricultural Science, 24 (No 2) 2018, 335-340.

[8] Perekrest A., Shendryk V., Pijarski P., Parfenenko Y., Shendryk S. Complex information and technical solutions for energy management of municipal energetic. Proceedings Volume 10445, Photonics Applications in Astronomy, Communications, Industry, and High Energy Physics Experiments 2017; 1044567 (2017).

[9] Perekrest A., Chornyi O., Mur O., Nikolenko A., Kuznetsov V., Kuznetsova Y. Preparation and preliminary analysis of data on energy consumption by municipal buildings. Eastern-European Journal of Enterprise Technologies/ Volume 6, Issue 8-96, 2018, Pages 32-42.

[10] Iberla K. Faktornyj analiz. Per. s nem. V. M. Ivanovoj. M.: Statistika, $1980-398$ s.

\title{
Рейтинг об'єктів енергоспоживання на основі методу основних компонентів
}

\author{
А. Л. Перекрест \\ Україна
О. В. Вовна
ДНТУ,
Україна

КНУ ім. Михайла Остроградського,

\author{
В. О. Огарь \\ КНУ ім. Михайла Остроградського, \\ Україна \\ М. О. Кущ-Жирко \\ КНУ ім. Михайла Остроградського, \\ Україна
}

\begin{abstract}
Забезпечення комфортних умов в цивільних будівлях потребує виконання завдань моніторингу та прогнозування витрат енергетичних ресурсів, а також енергоефективного керування тепловими інженерними системами та їх обладнанням. Впровадження відповідних рішень 3 автоматизації та моніторингу дозволяс накопичувати значний обсяг даних. Для підвищення інформативності аналізу ефективності використання енергоресурсів при функціонуванні цивільних будівель розроблено модель їх інформаційного ранжування 3 використанням кореляційного аналізу та методу головних компонент. Для прийнятих початкових умов про електроспоживання та теплоспоживання навчальних корпусів університету на основі міждисциплінарної методології аналізу даних (CRISP-DM) визначені базові показники та отримана оцінка матриці коефіціснтів кореляції їх взаємозв'язку. Певні дані (зовнішній об'єм та площа будівлі та середні значення температури для даного регіону за нормою) отримуються 3 технічної документації будівель та доступні 3 відкритих джерел, інші (кількість спожитої теплової та електричної енергії, внутрішня температура у приміщенні) визначаються в процесі експлуатації і характеризують ефективність використання енергетичних ресурсів в будівлі. На початковому етапі проведено кореляційний аналіз взаємозв'язку основних параметрів, що характеризують будівлі та споживання ними енергетичних ресурсів. Для зниження розмірності ознакової множини даних та виявлення гомогенних груп об'сктів енергоспоживання використано метод головних компонентів. Отримані чотири компоненти пояснюють біля 90 \% дисперсії початкових даних та характеризують ефективність використання енергоресурсів по температурі, об'єму та коефіціснту градусо-діб опалювального сезону. Отримані результати рекомендовано до впровадження в сучасних системах енергетичного моніторингу та муніципального енергетичного менеджменту в якості прикладних моделей для діагностування нештатних ситуацій та обгрунтованого прийняття управлінських рішень.
\end{abstract}

Ключові слова - будівлі; енергоспоживання; головні компоненти; машинне навчання; сегментація даних. 